\title{
Root Rot and Stem Decay Following Commercial Thinning in Western Hemlock and Guidelines for Reducing Losses
}

\section{G. W. WALLIS and D. J. MORRISON}

Department of the Environment, Canadian Forestry Service,

Pacific Forest Research Centre,

Victoria, B.C.

\begin{abstract}
Significant losses can occur following thinning in western hemlock (Tsuga heterophylla (Raf.) Sarg.) if stump protection is not practised and attention is not given to minimizing stem and root injuries. As many as 12 new Fomes annosus root rot centers per hectare were created by a low thinning that removed only about 250 trees, when stumps were not treated. An annual loss to decay of $0.75 \%$ of the gross volume was recorded in trees severely injured during logging. Procedures for reducing losses to decay are given.
\end{abstract}

\section{Résumé}

Des pertes significatives peuvent survenir à la suite d'éclaircies dans les boisés de Pruche occidentale (Tsuga heterophylla (Raf.) Sarg.), si on ne cherche pas à protéger les souches et à tenir au minimum les blessures aux tiges et racines. Les auteurs signalent jusqu'à 13 centres de pourriture par Fomes annosus, par hectare, lorsqu'un mauvais éclaircissement n'enleva que 250 arbres et qu'on négligea de traiter les souches. On a enregistré une perte annuelle de $0.75 \%$ du volume brut due à la carie, dans des arbres sérieusement blessés lors de l'exploitation. Sont exposés ici certains procédés permettant de réduire ces pertes.

The continued depletion of mature timber in the coastal forest region of British Columbia has directed attention to the management of secondgrowth stands to supply the demand for wood products. Western hemlock (Tsuga heterophylla (Raf.) Sarg.) is a major component of many of these coastal stands. The B.C. Forest Service estimates that in the Vancouver Forest District the immature hemlock type extends over 65,500 ha $(162,000 \mathrm{ac})$ and is the principal species on another 125,000 ha $(308,000 \mathrm{ac})$.

The overstocked nature of many young coastal stands makes it inevitable that thinning be considered as a means of improving stand quality. Malmberg (1965) found that hemlock 30 years old or less responded well to release. However, for hemlock, that has the disadvantages of thin bark, high susceptibility to infection and rapid deterioration by wood decay fungi, thinning may result in a decrease rather than an increase in usable wood volume.

This report, utilizing published data from the Pacific Northwest U.S. and results of studies in British Columbia, attempts to forecast losses following thinning in western hemlock stands. Most losses in second-growth stands are attributable to root rot originating from stumps of the previous and existing crops, and to stem decay fungi that enter through scars on the bole and roots. Care during thinning will help to significantly reduce scarring. However, some scarring is inevitable, as are stump tops; consequently, practices to minimize infection from these sources are recommended.

\section{Losses originating from infected stumps}

\section{Stumps of the previous stand}

Fomes annosus (Fr.) Karst causes extensive decay in old-growth western hemlock in the $\mathrm{Pa}$ cific Northwest States and British Columbia (Englerth 1942; Buckland, et al 1949). When roots of the existing stand contact infected roots of old-growth stumps, the fungus readily grows onto the healthy roots (Wallis and Reynolds 1970). Infection centers of 15 to 20 trees originating from old-growth stumps were observed in a 40 year-old hemlock stand in B.C.; the decay reached heights of 12 feet in the stems. In thinned stands examined by Driver and Wood (1968), 10 to $57 \%$ of the stumps were infected by $F$. annosus. Similarly, a clear-cut hemlock stand on Vancouver Island had $10 \%$ of the stumps colonized. In both regions, infections originated from stumps of the previously logged stands.

Currently, short of high-cost land clearing or whole-tree harvesting, no method is known to render colonized stumps and roots innocuous. However, knowledge of the level of stump colonization present on a site is essential when deciding on practices to reduce levels of infection.

\section{Stumps created by thinning}

Fresh stumps of most coastal species, particularly western hemlock, are susceptible to infection by $F$. annosus spores (Wallis and Reynolds 1970). Spores deposited on fresh stumps germinate and the mycelium grows into and decays the stumps and roots. Once established in hemlock stumps, $F$. annosus grows up to $75 \mathrm{~cm}(30$ inches) per year through the wood (Wallis and Reynolds 1970).

An experimental thinning, conducted monthly for 1 year, showed that coastal hemlock stumps are susceptible to infection throughout the year (Morrison and Johnson 1970). Stump colonization was measured 6 months and 5 years after thinning. During this interval, the percentage of stumps with $F$. annosus declined from about 61 to 11 . The extent to which $F$. annosus is able to colonize a stump is influenced primarily by competition from other fungi. Five years after thinning, the extent of colonization of stumps by $F$. 
annosus ranged from near complete to confinement in a small part of the stump by competing fungi such as Armillaria mellea (Vahl ex Fr.) Kummer.

In 1967-68, intermediate trees were thinned from 1.2 ha $(3 \mathrm{ac}$ ) of a 40 -year-old hemlock stand on Vancouver Island. Nineteen infection centers originating from stumps of the previous stand were recorded. Five years following treatment, 30 of the thinning stumps were colonized by $F$. annosus. Competing organisms confined colonization to above-ground portions of 16 of these stumps. In the remaining 14 however, $F$. annosus had colonized the roots and was providing a source of inoculum for additional infection centers.

\section{Stump protection}

Stump surfaces may be protected against infection by $F$. annosus by applying a competitive fungus or an inhibitory chemical. Peniophora gigantea (Fr.) Massee has been used successfully on pines in Europe and the southeastern United States; however, it does not inhibit satisfactorily the growth of $F$. annosus in stumps of conifers in coastal British Columbia. A search for a suitable biological control for $F$. annosus in B.C. is in progress.

Two chemicals, urea and sodium nitrite, that proved effective in other regions, failed to control stump infection in hemlock (Weir 1969). Borax, as a dry powder, $10 \%$ aqueous suspension or $20 \%$ in glycol, has given the best results in coastal B.C., Washington and Oregon (Weir 1969; Russell et al. 1973). However, the effectiveness of borax varies with the time of year, being poor during periods of heavy precipitation (Edmonds et al. 1969; Russell et al. 1973).

In recent trials in a 45-year-old hemlock stand on Vancouver Island, stumps of trees cut over a 2-year period were treated with borax (dry powder and $10 \%$ in water), zinc chloride $(10 \%$ in water $)$ and ammonium sulphamate $(20 \%$ in water). Stumps were sampled 6 months after treatment. Zinc chloride was superior to borax and ammonium sulphamate in preventing infection by $F$. annosus; ammonium sulphamate was as effective as borax (Table 1). Ammonium sulphamate enhanced stump colonization by saprophytic fungi but was more costly than the other chemicals. As before, borax failed during periods of high precipitation.

\section{Losses from infection through scars}

Potential for loss following infection through scars by wood decay fungi may best be illustrated by a quotation from Englerth and Isaac (1944), who studied hemlock injured 12 years previously: "It is difficult to evaluate the exact
Table 1. Percentage of western hemlock stumps colonized by Fomes annosus following treatment with $10 \%$ zinc chloride, powdered and $10 \%$ borax, $20 \%$ ammonium sulphamate and distilled water (control) (10 stumps per treatment)

\begin{tabular}{|c|c|c|c|c|c|}
\hline \multirow[b]{2}{*}{ Month } & \multirow{2}{*}{$\begin{array}{c}\text { Zinc } \\
\text { chloride }\end{array}$} & \multicolumn{2}{|c|}{ Borax } & Ammonium & \multirow{2}{*}{ Control } \\
\hline & & $10 \%$ & Dry & sulphamate & \\
\hline July & 0 & 0 & - & - & 100 \\
\hline November & - & 10 & - & 20 & 0 \\
\hline February & 0 & 0 & - & 30 & 60 \\
\hline May & 0 & 20 & - & 30 & 90 \\
\hline December & 20 & 20 & 50 & 10 & 80 \\
\hline February & 0 & 20 & 20 & 0 & 70 \\
\hline April & 0 & 20 & 10 & 10 & 70 \\
\hline July & 0 & 0 & 0 & 40 & 90 \\
\hline
\end{tabular}

amount of damage done by this decay ( $F$. annosus) in the 12-year period, but it is evident that it has gone a long way toward destroying the log that contained the injury and, in most instances, this was the butt log." Wright, et al. (1947) dissected 5- to 30-year-old logging wounds on mature hemlock and found that $41 \%$ of the gross increment of the infected trees since logging was lost to decay; $F$. annosus was responsible for $50 \%$ of the decay. Curves for assigning decay volumes to scars of known age and size, published by Wright and Isaac (1956), are recommended for predicting losses in overmature trees.

A number of studies have shown that immature trees may also suffer significant loss to decay following injury. In one study in 90-year-old hemlock damaged 17 years earlier (Shea 1960), 91\% of trunk scars had associated decay; $82 \%$ of the decay volume occurred in the stump and first log, illustrating the importance of skidding as a source of injury. In a study of 10-year-old scars on 50-year-old hemlock, decay resulted in a net volume loss during the period since treatment (Shea 1961). Hunt and Krueger (1962) suggest that thin bark, fluted trunks and exposed roots of hemlock make it particularly vulnerable to skidding damage.

Losses following logging injury to secondgrowth hemlock was measured by the authors in three areas in coastal British Columbia. Three hundred and ten scars were analyzed in five age and five size classes. Most difficult to locate were scars in the 25-year-old age class; results are presented to indicate the extent of losses that can be expected with scars of this age.

The percentage of 5- to 15-year-old scars in the $9 \mathrm{dm}^{2}\left(1 \mathrm{ft}^{2}\right)$ class infected was about half that in larger size classes (Table 2). They were, for the most part, associated with a small volume of decay (Table 3). Rapidly developing fungi, such as $F$. annosus, occasionally become established in these small scars (Table 3, 20-year-old scars), and have the potential for causing substantial loss.

Decay destroyed an increasingly larger percent- 
Table 2. Average percentage of scars 5 to 25 years of age on coastal western hemlock infected with wood decay fungi

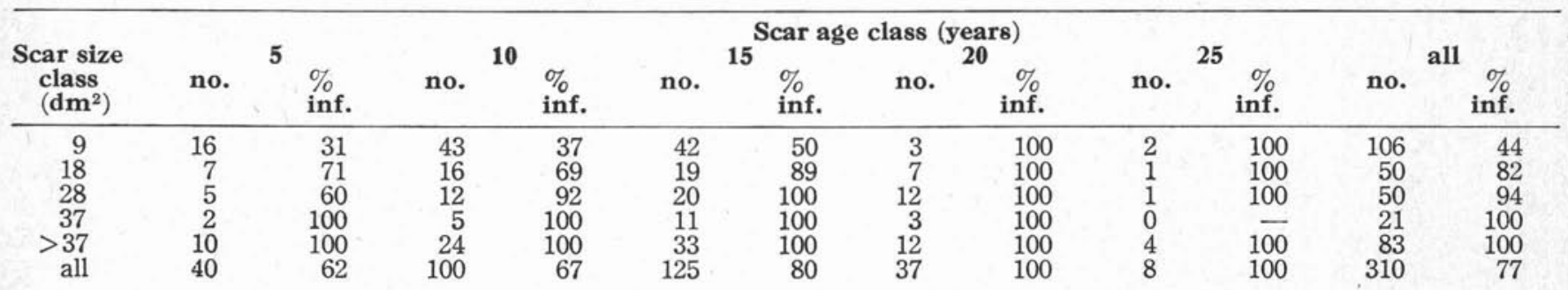

Table 3. Average percentage of current merchantable cubic-foot volume of coastal western hemlock decayed 5 to 25 years after logging damage; in trees to a 4-inch top and in the first 16-foot log

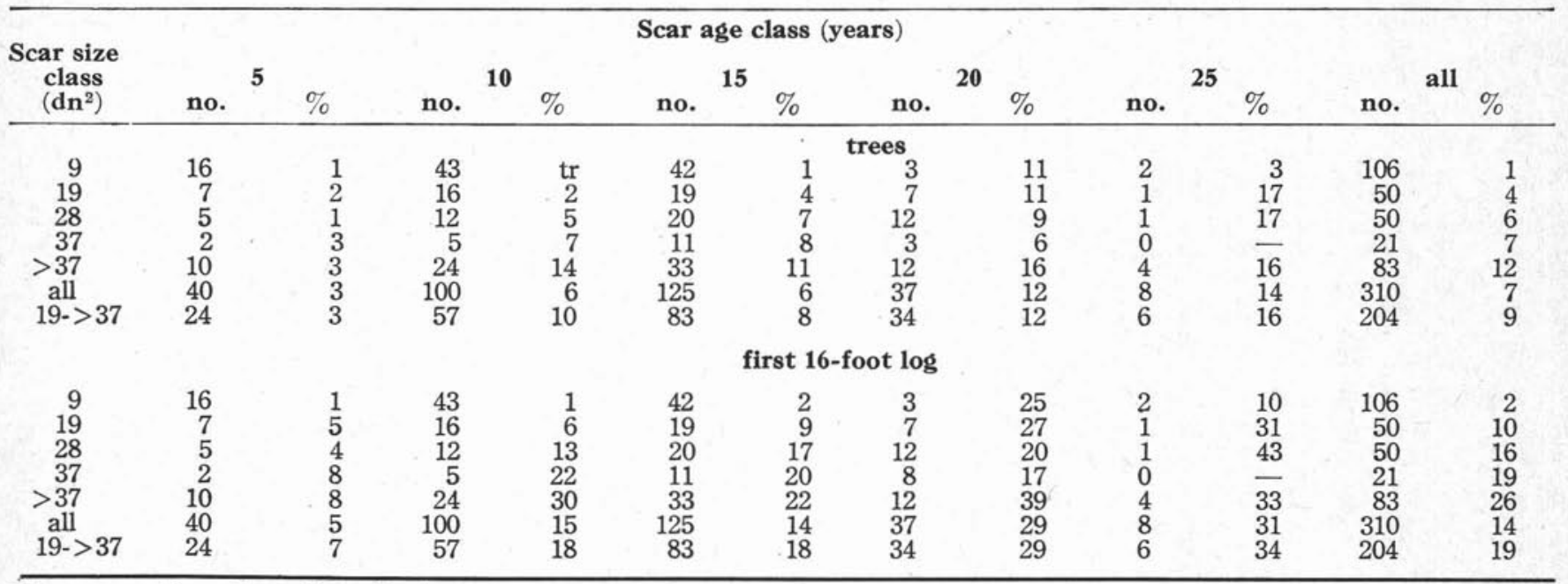

iPercentage of merchantable cubic-foot volume.

Table 4. Average percentage of infected scars and associated volume of decay attributable to various wood-decay fungi for each scar age class on western hemlock

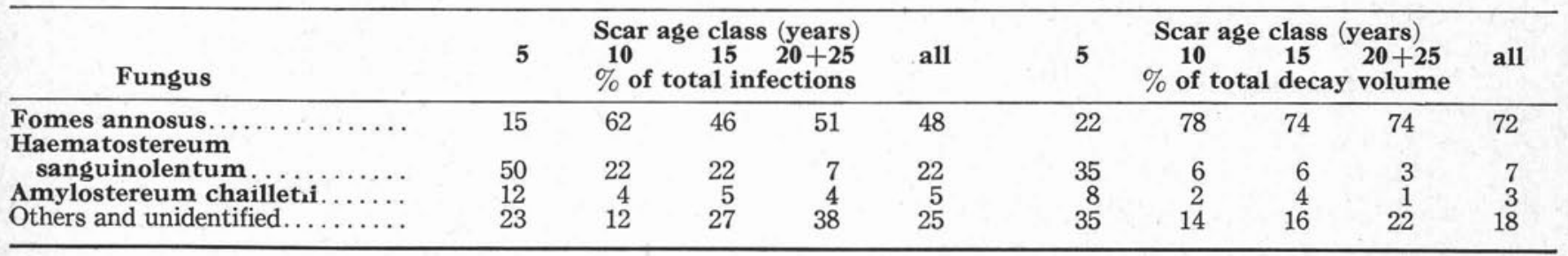

age of the volume of injured trees, with increasing size and age of scars. Over $90 \%$ of the scars examined were near the base of the trees; consequently, most decay was located in the highvalue butt logs. The results indicate that in trees with scars greater than $9 \mathrm{dm}^{2}$, about 0.5 to $0.75 \%$ of the gross volume will be lost annually. Since most of this volume is in butt logs, the volume of decayed wood in the first 16-foot log will increase annually at a rate of about 1 to $1.5 \%$ of the gross volume.

Wide scars were associated with a greater percentage (at least double) loss to decay than long, narrow scars. The rate of progression of decay above injuries was 2 to 3 times greater than below the injuries.

Deep scars (wood gouged) and injuries to roots were associated with a higher percentage loss than superficial bole injuries.

Decay associated with scars was confined to those tissues laid down prior to injury. Consequently, tree diameter at the time of scarring was a significant factor governing decay volume. Scars in the upper-bole, small-diameter logs were associated with a lower percentage loss than similar injuries in lower-bole, large-diameter logs. 
Ten species of decay fungi were isolated from rot associated with scars. The species of decay fungi established in the injury was the most important factor governing the amount of decay (Table 4). For example, although $F$. annosus colonized only about half the scars, the loss caused by this rapidly growing fungus was $72 \%$ of the total decay volume. On the average, trees infected by $F$. annosus contained at least twice the percentage loss as those infected by any other fungus. Together, $F$. annosus and the second most common decay fungus, Haematostereum sanguinolentum (Alb. + Schw. ex Fr.) Powzar, were responsible for $70 \%$ of infections and nearly $80 \%$ of the decay volume. In contrast to $F$. annosus, $H$. sanguinolentum was more important in young scars and less significant in scars over 10 years of age.

\section{Conclusion}

Results to date indicate that significant losses will be incurred following thinnings in western hemlock if stump protection is not practiced and attention is not given to minimizing stem and root injuries.

At least $12 F$. annosus root rot centers per ha were created by a low thinning that removed about 250 trees per ha. The number of infection centers can be expected to increase in proportion to the number of trees cut. When root infection is initiated early in a rotation, each infection center may contain 15 to 20 trees and a major portion of the heartwood of the butt logs may be decayed by age 40 .

Additional losses will be caused by decay fungi entering through scars; annual losses as high as $0.75 \%$ of the gross volume of injured trees may be expected. The volume lost to decay in thinned stands is related to the number of injured stems and hence to the care exercised in reducing injuries.

\section{SILVICULTURAL AND CONTROL PROCEDURES RECOMMENDED FOR USE IN REDUCING LOSSES FROM DECAY FOLLOWING THINNING}

1. Thin stands as young as is practical when stem diameters are small, to minimize scarring, size of scars and decay.

Incidence of infection and subsequent volumes of decay are significantly smaller in scars less than $9.3 \mathrm{dm}^{2}\left(1 \mathrm{ft}^{2}\right)$ in area. Decay following injury will be confined to wood laid down before the time of injury, thus the smaller the diameter of the tree when injured, the smaller the volume of wood susceptible to decay.

2. Use buffer trees (remove at end of operation) and buffer pads on trees along skid trails to minimize scarring on residual trees.
3. Snow and frozen soil protect against root injuries; consequently, winter injuries are usually smaller and less deep than those made in summer (Kärkkäinen 1973; Isomaki and Kallio 1974).

4. Suspend thinning operations during the period of sap flow.

Bark is easily rubbed off during spring and early summer and damage may be excessive even when considerable care is taken.

5. Favor thick-barked species, for example, Douglas-fir (Pseudotsuga menziesii (Mirb.) Franco), as crop trees when the site permits.

Douglas-fir is less susceptible to injury and more resistant to infection and wood deterioration by wood decay fungi than are hemlock and the true firs. Western red cedar (Thuja plicata Donn), although a thin-barked species, is highly resistant to infection and decay entering through scars.

6 . In pole-sized stands of western hemlock, incidence and size of sunscald injuries are greater after heavy than after a light thinning.

Nearly every sunscald injury on dissected pole-sized trees contained decay (Wright and Isaac 1956; Wallis et al. 1971).

7. Protect stumps against spore infection by $F$. annosus.

As soon as possible, preferably immediately after felling, cover stump surfaces generously with zinc chloride ( $10 \%$ aqueous solution) or, during dry seasons, with borax (dry powder or $10 \%$ aqueous suspension). A dye such as rhodamine $B$ should be added to permit a quick visual check of coverage and untreated stumps. Dry borax may be applied with a salt shaker-type container and solutions, using a pressure sprayer or squeeze bottle. Penetration and retention of chemical will be better if stump surfaces are flat.

8. Protect basal injuries against infection by wood decay fungi.

Basal injuries have a twofold hazard: they are entrance courts for wood decay fungi that decay injured stems and for root rot fungi, such as $F$. annosus, which, besides deteriorating the stem, grow into the roots, infect adjacent trees and perpetuate the disease for future rotations.

Preliminary trials indicate that protection can be achieved by applying, with a pressure sprayer, zinc chloride $(10 \%$ aqueous solution) to which has been added a commercial spreader-sticker.

\section{References}

Buckland, D.C., R.E. Foster and V.J. Nordin. 1949. Studies in forest pathology VII. Decay in western hemlock and fir in the Franklin River area, British Columbia. Can. J. Res. C, 27:312-332. 
Driver, Chas. H. and R.E. Wood. 1968. Occurrence of Fomes annosus in intensively managed young-growth western hemlock stands. Plant Dis. Rept. 52:370-372.

Edmonds, R.L., C.H. Driver and K.W. Russell. 1969. Borax and control of stump infection by Fomes annosus in western hemlock. Plant Dis. Rept. 53:216-219.

Englerth, G.H. 1942. Decay of western hemlock in western Oregon and Washington. Yale Univ., School of Forestry Bul. 50, 53 pp.

Englerth, G.H. and Leo A. Isaac. 1944. Decay of western hemlock following logging injury. Timberman 45(8):34 $35,56$.

Hunt, John and Kenneth W. Krueger. 1962. Decay associated with thinning wounds in young-growth western hemlock and Douglas-fir. J. For. 60:336-340.

Isomaki, Antti and Tauno Kallio. 1974. Consequences of injury caused by timber harvesting machines on the growth and decay of spruce (Picea abies (L.) Karst.) Acta Forestalia Fennica 136, 24 pp.

Kärkkäinen, Matti. 1973. On the properties of tree wounds due to timber transportation in thinning. Univ. Helsinki, Dept. of Logging and Utilization of Forest Products. Research Notes No. 22, 174 pp.

Malmberg, D.B. 1965. Early thinning trials in western hemlock (Tsuga heterophylla (Raf.) Sarg.) related to stand structure and product development. Univ. Wash., Ph.D. Thesis, $138 \mathrm{pp}$.

Morrison, D.J. and A.L.S. Johnson. 1970. Seasonal variation of stump infection by Fomes annosus in coastal British
Columbia. For. Chron 46:200-202.

Russell, K.W., J.H. Thompson, J.L. Stewart and C.H. Driver. 1973. Evaluation of chemicals to control infection of stumps by Fomes annosus in precommercially thinned western hemlock stands. State of Washington, DNR. Rept. 33,16 pp.

Shea, Keith R. 1960. Decay in logging scars in western hemlock and Sitka spruce. Weyerhaeuser Co., Forest Res. Note 25, 7 pp.

Shea, Keith R. 1961. Deterioration resulting from logging injury in Douglas-fir and western hemlock. Weyerhaeuser Co., Forest Res. Note 36, 5 pp.

Wallis, G.W. and G. Reynolds. 1970. Fomes annosus root and butt rot: a threat in managed stands in coastal British Columbia. For. Chron. 46:221-224.

Wallis, G.W., G. Reynolds and H.M. Craig. 1971. Decay associated with logging scars on immature western hemlock in coastal British Columbia. Dept. Fish. and Forest., Canada, Inform. Rept. BC-X-54.

Weir, L.C. 1969. Experiments in control of Fomes annosus root rot in Douglas fir and western hemlock. Plant Dis. Rept. 53: 910-911.

Wright, Ernst and Leo A. Isaac. 1956. Decay following logging injury to western hemlock, Sitka spruce and the true firs. U.S. Dept. Ag. Tech. Bul. 1148, 34 pp.

Wright, Ernst, Arthur S. Rhoads and Leo A. Isaac. 1947. Decay losses following logging injury in partially cut stands of western hemlock and Sitka spruce. Timberman $48(10): 52,54,72,74,76$

\section{FORESTERS TO WORK OVERSEAS}

\author{
Papua New Guinea \\ Malaysia
}

\section{Degree or Diploma Level}

Working overseas provides not only immeasurable insight into development problems, but also professional diversification and personal development.

For more information, contact -

CUSO,

Forestry Programme A04, 151 Slater Street, Ottawa, Ontario, K1P'5H5.
ANNOUNCING A NEW

TWO-VOLUME EDITION OF

"FOREST RESOURCE

MANAGEMENT"

Decision-making Principles and Cases

\author{
Edited by
}

Duerr, Teeguarden, Guttenberg and Christiansen

928 pages, complete 49 chapters

(available in 2-volume set only)

Single copies $\$ 11.95+80 \phi$ mailing, total $\$ 12.75$.

Also available to college book stores.

Send orders to:

O.S.U. BOOK STORES, INC.,

Dept. C, P.O. Box 489, Corvallis, OR 97330 . 